\title{
Políticas de línguas e educação escolar indígena no Brasil
}

\section{Language policies and indigenous schools in Brazil}

\author{
Rodrigo Bastos Cunha*
}

\begin{abstract}
RESUMO
Neste artigo, após uma breve revisão conceitual sobre planejamento e política lingüística, modelos de políticas de línguas e um caso exemplar de política lingüística no mundo, abordarei questões atuais de políticas de línguas no Brasil, como o ensino bilíngüe em escolas indígenas, o financiamento a pesquisas para documentação de línguas em extinção, a revitalização de línguas ou de variedades de línguas e investimento governamental em material didático específico para a educação indígena. ।

Palavras-chave: política lingüística; línguas indígenas; educação indígena.
\end{abstract}

\begin{abstract}
In this article, after a brief conceptual revision on language planning and policy, models of language policies and an exemplary case of language policy in the world, I will approach actual issues about languages policies in Brazil, such as the bilingual education in indigenous schools, the financing to research for documentation of languages in extinction, the revitalization of languages or their varieties and the governmental investment in specific didactic material for the indigenous education.
\end{abstract}

Keywords: language policy; indigenous languages; indigenous education.

* Doutorando em Lingüística Aplicada pelo IEL-Unicamp. Bacharel em Lingüística, com especialização em Jornalismo Científico e mestrado em Comunicação Social. Pesquisador do Labjor/ Unicamp. E- mail: brcunha@unicamp.br 


\section{Introdução}

O Brasil é, historicamente, um país multilingüe. Antes mesmo da chegada dos colonizadores portugueses, a diversidade de línguas indígenas aqui faladas era imensa. Aryon Rodrigues (1993, p. 83-103) estima que fossem cerca de 1.200. Durante a colonização, vieram para o país, além do português, línguas africanas, com os negros escravizados, e as primeiras línguas de imigrantes, que se tornariam mais diversas nos séculos posteriores. Essa multiplicidade de línguas convivendo no território nacional envolve questões lingüísticas complexas de comunicação e de acesso à informação e ao ensino. Embora seja um país multilingüe, Carlos Alberto Faraco (2002, p. 13-14) observa que o Brasil, "em geral, se reconhece como unilíngüe, confundindo hegemonia com unicidade". Assim, "a grande questão das centenas de línguas indígenas e aquela das dezenas de línguas de imigração não se configuram como um tema da nacionalidade e da cidadania".

A gênese do recém inaugurado Museu da Língua Portuguesa, na Estação da Luz, em São Paulo, ilustra bem isso. O lingüista Aryon Rodrigues, do Laboratório de Línguas Indígenas da Universidade de Brasília (UnB), foi um dos consultores para o desenvolvimento de conteúdo das telas multimídia daquele espaço. Ele revela, em depoimento à revista Ciência \& Cultura ${ }^{1}$, que a palavra "museu" surgiu durante o processo de sua concepção, que desde a origem já mostrava o foco no português, em detrimento das línguas minoritárias faladas no Brasil. O lingüista conta que o projeto foi apresentado inicialmente como Estação da Luz da Nossa Língua - e não como de Nossas Línguas, o que, segundo Rodrigues, teria sido o ideal para ele e para muitos outros que trabalham com questões indígenas, mas que certamente encontraria resistência. Depois, continua o lingüista, alguém de peso - cuja identidade, obviamente, ele não revela no depoimento - quis que fosse literalmente um museu. Daí surgiu a idéia de um Museu da Nossa Língua, que é como Rodrigues pensava que ia ser inaugurado. Segundo ele, é possível que, futuramente, seja concebido um Museu das Línguas do Brasil, com maior espaço para as numerosas línguas indígenas, para mais informações sobre as línguas africanas e sobre as mais de vinte línguas de minorias européias e asiáticas atualmente em uso no país. O problema é que só se conseguirá uma mobilização política - e financeira - para tal empreitada com muita dificuldade, justamente por se tratarem de minorias lingüísticas.

Mas mesmo quando se trata de problemas ligados à língua majoritária do

1 Ver "Museu expõe multiplicidade e história da língua portuguesa", em revista Ciência \& Cultura, n. 3, ano 58, de julho de 2006. 
Brasil, o português, Faraco (2002, p. 14) lembra que a discussão política das questões lingüísticas é ainda muito reduzida e precária. Uma ou outra questão pontual é levada para o debate político - e em certos casos, logo esquecida -, como o projeto de lei proposto em 1999 pelo deputado federal Aldo Rebelo, que pretendia restringir o uso de estrangeirismos no português brasileiro e foi engavetado após inúmeras críticas de lingüistas. De acordo com Faraco (2002, p. 14), a falta de discussão política sobre questões lingüísticas se dá "porque, apesar de sua dimensão e relevância social, elas não são ainda questões para a sociedade brasileira, isto é, elas não se apresentam como um problema de natureza política para o conjunto da sociedade, como algo que mereça controvérsia e debate".

Apesar desse quadro, em relação às línguas indígenas, uma parcela da sociedade - que inclui lideranças indígenas, educadores, pesquisadores, políticos e organizações não governamentais - tem se mobilizado cada vez mais para influenciar políticas lingüísticas no país, embora os resultados dessa atuação ainda sejam incipientes. Mas como pondera James Tollefson (1991, p. 188), "os direitos lingüísticos são baseados em luta" e "alcançar algum quinhão dos direitos não finda a luta; simplesmente muda a sua natureza".

Neste artigo, após uma breve revisão conceitual sobre planejamento e política lingüística, modelos de políticas de línguas e um caso exemplar de política lingüística no mundo, abordarei questões atuais de políticas de línguas no Brasil. Entre essas questões estão o ensino bilíngüe em escolas indígenas, o financiamento a pesquisas para documentação de línguas em extinção, a revitalização de línguas ou de variedades de línguas e o investimento governamental em material didático específico para a educação indígena. $\mathrm{O}$ tema da educação escolar indígena pode suscitar uma discussão bem mais ampla do que a que envolve a questão lingüística: o respeito aos "conhecimentos, as tradições e os costumes de cada povo, valorizando e fortalecendo a identidade étnica" (cf. SILVA, 1999, p. 67); "a necessidade de uma outra educação formal, decorrente da situação de contato com a sociedade nacional", ou seja, diferentes "tipos de escolas que os diversos povos indígenas reivindicam” (cf. SILVA, 1994, p. 46). Porém, o foco deste artigo será a atuação relacionada às línguas indígenas do país. 


\section{Políticas linguísticas: conceitos, modelos e um exemplo}

De acordo com Robert Cooper (1989, p. 29), “o planejamento lingüístico é dirigido para uma variedade de fins e abarca uma variedade de significados" e "não há uma única definição de planejamento lingüístico universalmente aceita". Segundo ele, o termo inglês language policy (política lingüística) às vezes aparece na literatura acadêmica como sinônimo de language planning (planejamento lingüístico), "mas freqüentemente ele se refere às metas do planejamento lingüístico" (COOPER, 1989, p. 29). Para os fins deste artigo, considero que em português, o termo "política lingüística" pode ser usado de forma genérica, tanto para metas quanto para ações sobre o uso das línguas. Além de ele se adequar às definições de language planning e seus principais focos, apresentados por Cooper, abarca, no caso das línguas indígenas, a sua documentação, a publicação de material didático e o ensino bilíngüe, e abrange não apenas decisões governamentais, mas também a participação de pesquisadores, educadores, organizações não governamentais e lideranças indígenas como atores políticos.

A primeira definição que Cooper apresenta como sendo a que introduziu o termo language planning na literatura é a de Haugen (1959, apud COOPER, 1989 , p. 29): "a atividade de preparar uma ortografia, uma gramática e um dicionário normativos para orientação de escritores e falantes em uma comunidade de fala não homogênea". Esta definição se restringe a um dos focos do planejamento lingüístico, que é o planejamento do corpus da língua. Cooper apresenta, ainda, outras doze definições, uma segunda, do próprio Haugen, de 1969, e outras de diversos pesquisadores ligados à Sociologia da Linguagem ou à Lingüística Aplicada, que aparecem em trabalhos publicados nas décadas de 1970 e 1980. Aquela primeira, de Haugen, dá um caráter normativo ao planejamento. As reformas ortográficas, que no caso do português brasileiro são propostas pela Academia Brasileira de Letras, fazem parte do planejamento do corpus de uma língua. Mas a própria seleção da grafia para representação de línguas de comunidades originalmente ágrafas também se inclui nesse item do planejamento lingüístico, e como veremos adiante, o trabalho descritivo é muito mais produtivo do que a mera normatização, e pode contribuir para a discussão sobre os padrões a serem adotados na escrita. Cooper observa que "se o estudo de planificação lingüística é descritivo, isto é, o estudo do que de fato acontece [no uso da língua], então a concepção de planejamento lingüístico como um direcionamento ideal é inapropriada" (1989, p. 42).

O segundo foco do planejamento lingüístico apontado por Cooper (1989, 
p. 32) é o do planejamento do status da língua, ou seja, “o reconhecimento, por um governo nacional, da importância ou posição de uma língua em relação a outras", o que envolve a designação das línguas para determinadas funções, como meio de instrução, língua oficial ou veículo de comunicação de massa. $\mathrm{O}$ ensino bilíngüe está ligado ao planejamento do status de uma língua; mas em relação a uma língua majoritária e oficial, como o português, o status de uma língua minoritária usada como meio de instrução, como as línguas indígenas brasileiras, pode ter várias gradações.

Terezinha Machado Maher (2006, p. 3) explica que se o bilingüismo do falante "é considerado, não um atributo, mas um 'problema', o objetivo [das instituições de ensino] será fazer o aluno abdicar de sua língua materna e se tornar monolíngue" na língua dominante, no nosso caso, a língua portuguesa. Essa é a perspectiva do Modelo Assimilacionista de Submersão, que segundo Maher, foi "o modelo adotado por algumas missões religiosas e órgãos do governo brasileiro junto aos povos indígenas durantes anos a fio". E como alerta Tollefson (1991, p.170), mesmo quando a política lingüística protege direitos lingüísticos das minorias, ela pode ser uma forma de controle encoberto do Estado, pois "os direitos lingüísticos são subordinados à estrutura de poder e dominação" estabelecida.

Um caso exemplar que ele aponta é o da Austrália, que tem o inglês como língua oficial, mas quase um quinto da população falante de outro idioma como primeira língua, entre as quase 150 línguas aborígenes e em torno de 75 a 100 línguas de imigrantes. No final dos anos 1970, o primeiro ministro australiano formou um comitê para rever os programas e serviços voltados para os imigrantes, que viviam conflitos étnicos, trabalhavam em empregos mal remunerados e tinham baixos níveis de escolaridade. O relatório do comitê foi escrito em nove idiomas além do inglês - que tiveram, na ocasião, um status diferenciado das outras dezenas de línguas faladas no país -, o que, segundo Tollefson (1991, p. 174), refletia a sua recomendação de que "a política federal deveria acabar com a ênfase de longas décadas na assimilação, e mudar para uma política que conseqüentemente viria a ser chamada multiculturalismo ou pluralismo cultural". Porém, embora o relatório sugerisse que os falantes de outras línguas que não o inglês deveriam ter igual acesso aos serviços governamentais de saúde e seguridade social e à informação dos meios de comunicação, ele não fazia nenhuma recomendação similar para a educação e para o emprego. De acordo com Tollefson (1991, p. 175), os conservadores contrários ao relatório diziam que "o próprio argumento do comitê definia diversidade cultural como o problema ao invés da solução".

$\mathrm{Na}$ década de 1980, surgiram outras iniciativas na política lingüística nacional da Austrália: primeiro, a recomendação do ensino bilíngüe pelo se- 
nado; e depois, o reconhecimento do multilinguismo e do multiculturalismo como centrais na história e identidade australianas. Embora essas iniciativas possam ser consideradas um avanço em relação à política dos anos 1970, elas se aproximam de um modelo tão perverso quanto o Assimilacionista de Submersão. Trata-se do Modelo Assimilacionista de Transição, no qual "a língua de instrução, nas séries iniciais, é a língua materna do aluno. Assim que a criança é nela alfabetizada, assim que ela entende o funcionamento da escrita", vai-se introduzindo a língua majoritária aos poucos, "até que a língua materna seja totalmente excluída do currículo escolar" (MAHER, 2006, p. 3). O relatório australiano que reconhecia a importância histórica do multilinguismo delineava como a mais alta prioridade na política de educação lingüística o "inglês para todos", aceitando o princípio básico dos relatórios precedentes de que "o inglês deveria continuar desempenhando um papel dominante na vida australiana" (TOLLEFSON, 1991, p. 179).

A idéia do multiculturalismo, por outro lado, levou à recomendação de fundos para programas de documentação e preservação de línguas aborígenes, iniciativas ligadas ao que Cooper (1989) chama de planejamento do corpus como parte da planejamento lingüístico, mas que de certa forma também têm a ver com o planejamento do status das línguas aborígenes, na medida em que se fazia a recomendação do seu uso como línguas de instrução para as crianças que não eram fluentes em inglês. Já a ênfase da política australiana no ensino de inglês como segunda língua para os imigrantes e seus descendentes é exatamente o que Cooper aponta como terceiro foco dentro do planejamento lingüístico, que se soma ao foco no corpus e no status: o foco na aquisição da língua. Segundo Cooper (1989, p. 33):

Quando o planejamento é direcionado para aumentar os usos da língua, ele recai na rubrica do planejamento do status. Mas quando ele é direcionado para aumentar o número de usuários - falantes, escritores, ouvintes e leitores - então há uma categoria analítica separada [a da aquisição] como foco do planejamento lingüístico.

Nesse terceiro foco apontado por Cooper também recaem os casos de revitalização de línguas ou variedades de línguas ameaçadas de extinção, que abordaremos adiante.

Um dos méritos do relatório australiano que reconhecia o multilinguismo como central na história e na identidade do país - além desse próprio reconhecimento - foi reconhecer também outras duas coisas em relação à política educa- 
cional e à política lingüística: elas não eram suficientes para manter as línguas ameaçadas por poderosas forças econômicas e sociais (TOLLEFSON, 1991, p. 181), assim como não eram suficientes para mudar a posição socioeconômica de seus falantes. $\mathrm{O}$ entrave na condição dos imigrantes e aborígenes, portanto, não estaria no bilingüismo das minorias ou no fato de elas não se tornarem monolíngues na língua majoritária. $\mathrm{O}$ bilingüismo das minorias, quando avaliado positivamente - da mesma forma que é no caso de uma segunda língua de prestígio, como o inglês ou o francês, para um falante de português como língua materna -, dá margem a um terceiro modelo de política de língua, o Modelo de Enriquecimento Lingüístico, cujo "objetivo educacional é garantir a manutenção e desenvolvimento da língua minoritária na escola" e insistir "na importância de que essa seja a língua de instrução ao longo de todo o processo de escolarização" (MAHER, 2006, p. 4). Feitas essas apresentações conceituais e de modelos de políticas de línguas, vamos a fatos recentes sobre esse campo no Brasil.

\section{Políticas de línguas no Brasil}

Desde o século XVI, logo após a chegada dos portugueses ao Brasil, a educação escolar no país atinge comunidades indígenas, pautada, a princípio, pela catequização feita pelos missionários jesuítas, e posteriormente, pela integração forçada dos índios à sociedade nacional, pelos programas de ensino do extinto Serviço de Proteção aos Índios. Nas últimas duas décadas, a partir da mobilização dos próprios índios, essa situação vem mudando gradativamente, e nas comunidades indígenas onde o contato com o não-índio já é antigo e a cultura $^{2}$ e a língua herdadas dos portugueses predominam, a escola passou a ser vista como um espaço para o resgate da identidade étnica desses povos.

A política educacional voltada para os índios começou a mudar no Brasil a partir da Constituição Federal promulgada em 1988, na qual já ecoa, em parte, a Declaração Universal dos Direitos Lingüísticos sugerida um ano antes, em Recife (PE), pela Associação Internacional para o Desenvolvimento da Comunicação Intercultural, uma agência da Unesco. O artigo 210 da Constituição, embora reafirme a imposição da língua portuguesa no ensino fundamental brasileiro - posta em prática, inicialmente, no século XVIII, pelo Marquês de Pombal -, assegura às comunidades indígenas a possibilidade de também utilizar nas

2 As culturas são entendidas aqui “como sistemas de valores, de representações e de comportamentos que permitem a cada grupo identificar-se, localizar-se e agir em um espaço social que o cerca" (CUCHE, 2002, p. 108) 
escolas suas línguas maternas e processos próprios de aprendizagem, uma primeira sinalização de mudança no planejamento de status de línguas minoritárias brasileiras, com a abertura para o seu uso como meio de instrução.

Em dezembro de 1996, o governo federal cria a Lei de Diretrizes e Bases (LDB) da Educação Nacional, que dedica dois capítulos (o 78 e o 79) ao ensino voltado para os índios. A LDB estipula que a União deve desenvolver programas de ensino e pesquisa para oferecer educação escolar bilíngüe e intercultural aos povos indígenas, com o objetivo de proporcionar a eles a recuperação de suas memórias históricas, a reafirmação de suas identidades étnicas e a valorização de suas línguas e conhecimentos tradicionais. O planejamento de status de línguas, aqui, colocando o ensino bilíngüe como uma oferta a ser dada e apoiada pelo Estado, começa a se consolidar.

Antes mesmo dessa regulamentação, já surgia uma demanda, por parte dos indígenas, por um ensino diferenciado em suas comunidades. Em novembro de 1999, as escolas voltadas para os índios - até então, indiferenciadas das chamadas "escolas rurais" - passaram a ser tratadas como instituições de ensino com diretrizes específicas, a partir da Resolução n ${ }^{\circ} 3$ publicada pela Câmara de Educação Básica do Conselho Nacional de Educação. Em 2000, a Câmara dos Deputados decreta o Plano Nacional de Educação e estipula entre suas metas a criação da categoria oficial de "escola indígena" para assegurar a especificidade do modelo de educação intercultural e bilíngüe.

Entretanto, grande parte das línguas indígenas, para serem inseridas nas escolas bilíngües que iriam surgir a partir daí, ainda careciam de um planejamento de corpus: no caso de línguas originalmente ágrafas. Isso envolve tanto a definição da grafia a ser adotada na escrita quanto o estudo do funcionamento da língua para descrição de sua gramática, a elaboração de dicionários e a produção de material didático em língua indígena (ou bilíngüe). Algumas línguas já tinham um considerável material de estudos lingüísticos sobre elas, como o kamaiurá, que teve a primeira gramática descritiva moderna de uma língua indígena do Brasil publicada em 2000, escrita por uma brasileira, a lingüista Lucy Seki, da Unicamp $^{3}$. Muitas línguas, no entanto, têm estudos apenas incipientes sobre elas e outras nunca haviam sido documentadas.

A situação não é muito diferente ao redor do mundo: a maior parte dos livros de referência aponta entre 5 mil e 6 mil línguas faladas atualmente ${ }^{4}$, e há

3 Ver "Lucy Seki e o indigenismo", na revista ComCiência no 15, de novembro de 2000. Em 1595, o jesuíta português José de Anchieta publicou a Arte de gramática da língua mais usada na costa do Brasil, sobre a língua geral derivada do tupinambá.

4 Ver CRYSTAL, David. The Cambridge encyclopedia of Language (1997). 
quem estime que dois terços delas estarão extintas no século XXI ${ }^{5}$. Em 1993, o lingüista Aryon Rodrigues, da UnB, já havia feito um balanço alarmante da situação lingüística no Brasil. Na época, ele estimava que cerca de 180 línguas ainda eram faladas no país, e que esse número representava no máximo $15 \%$ da quantidade de línguas que existia no Brasil há 500 anos. De acordo com esse autor, a redução drástica, por extinção, de $85 \%$ ou mais, na diversidade lingüística indígena do Brasil, corresponde, quase diretamente, à redução dos próprios povos indígenas. Essa perspectiva levou entidades governamentais (como $\mathrm{CNPq}$ e Fapesp) e não governamentais a financiar iniciativas para a preservação de línguas. Exemplos internacionais são a holandesa Wotro e a Fundação Volkswagen, uma instituição alemã de fomento à pesquisa. Esta última destinou ao longo de cinco anos, entre 2000 e 2005, US\$ 1,6 milhão para pesquisas lingüísticas voltadas para a documentação de oito línguas ameaçadas de extinção no mundo, três delas faladas no Brasil, no Parque Nacional Xingu.

As pesquisas lingüísticas que receberam apoio da fundação alemã foram o estudo do trumai, por Raquel Guirardello, do Instituto Max Planck de Psicolinguística (Holanda); do kuikuro, por Bruna Franchetto, do Museu Nacional (UFRJ); e do aweti, por Sebastian Drude, da Universidade Livre de Berlim. Segundo Guirardello ${ }^{6}$, que já tinha experiência de mais de 10 anos de trabalho no Xingu, em 2000, menos da metade dos 120 Trumais que ali viviam, ainda falava a língua de seus ancestrais.

Além do planejamento de corpus da língua, com a sua documentação, e do planejamento de status, com o seu uso como língua de instrução, casos como os da língua trumai mostram que é preciso um planejamento de aquisição. Isso para que as crianças indígenas aprendam e façam uso do idioma de seus ancestrais e ele não seja extinto com a morte dos índios mais velhos que ainda o falam ${ }^{7}$.

O grau de inserção da língua portuguesa entre os índios brasileiros é bastante variável de uma aldeia para outra. Entre os Aweti do alto Xingu, por exemplo, somente alguns homens adultos, entre 20 e 45 anos, sabem falar o português, segundo o alemão Sebastian Drude, que tem contato com esses índios desde 1998. O primeiro contato foi através de Bruna Franchetto, do Museu Nacional. Em sua primeira estada na aldeia, o alemão participou como instrutor

5 Ver estimativa de Steven Fischer mencionada em “A origem e o destino das línguas”, em revista ComCiência n. 23, de agosto de 2001.

6 Ver “As línguas indígenas da Amazônia”, em revista ComCiência n. 15, de novembro de 2000.

7 Meliá (1998, p. 30) observa, contudo, que "não é a escrita que vai salvar uma língua, mas que a sociedade que a fala a continue falando". A revitalização da língua através da escola é parcial e representa um retorno simbólico da língua indígena, não sendo garantia de uma revitalização plena em sua dimensão comunicativa (cf. MAHER, 1996, p. 165). 
no curso de formação dos professores indígenas do parque Xingu, organizado pelo Instituto Sócio-Ambiental (ISA), uma organização não governamental. Nessa etapa de seu trabalho de campo, ele contou com o apoio da Financiadora de Estudos e Projetos (FINEP) e do Museu Paraense Emílio Goeldi. Esse é um exemplo em que a política lingüística envolve vários atores, entre instituições públicas (FINEP, Museu Goeldi), privadas (Fundação Volkswagen), ONGs (ISA), pesquisadores e lideranças indígenas.

Foi Franchetto quem apresentou Drude aos Aweti. Ela também participou do projeto da Fundação Volkswagen, com o estudo e a documentação do kuikuro. Após lançar Os povos do Alto Xingu: história e cultura, pela editora da UFRJ, Franchetto fez um levantamento sobre o estágio atual de documentação de línguas indígenas no Brasil. Ela apresenta o resultado desse trabalho em seu artigo que integra o livro As línguas amazônicas hoje, lançado em 2000 pelo Instituto Sócio-Ambiental. Segundo Franchetto (2000), 34 línguas brasileiras possuem uma boa documentação, sendo 28 da região amazônica; 23 línguas não possuem documentação alguma, e um grande número (114, segundo os registros do Museu Nacional) possui documentação apenas parcial. As línguas com pouca ou alguma documentação incluem as que têm registro e análise de dados fonológicos e morfossintáticos.

De acordo com o Ministério da Educação (MEC), atualmente, há cerca de 170 línguas indígenas em uso nas comunidades de 210 etnias brasileiras, mas não há um número preciso de quantas das 2.322 escolas indígenas do país são bilíngües. Segundo Kleber Gesteira Matos ${ }^{8}$, coordenador-geral de Educação Escolar Indígena da Secretaria de Educação Continuada, Alfabetização e Diversidade (Secad) do MEC, a variedade de casos é muito grande e em cada localidade do país há uma realidade diferente. Ele explica que algumas comunidades já usam há algum tempo a língua indígena na escola; em outras, a língua indígena está sendo reintroduzida; algumas envolvem mais de uma língua indígena ou também o espanhol, no caso de povos das fronteiras; e existem, inclusive, comunidades monolíngues em que o professor trabalha na língua local e mais tarde introduz o português como segunda língua.

Portanto, não há como falar em um único modelo de política lingüística no país comparável ao assimilacionista do período colonial em que atuaram os missionários jesuítas, no qual "o objetivo era construir um universo de conceitos cristãos adequando o léxico indígena" e onde "termos enraizados nas tradições religiosas andinas são silenciados, porque são objeto de erradicação como parte das idolatrias" (ALFARO, 2001, p. 35). O que é possível dizer é que talvez não haja, no Brasil, um Modelo de Enriquecimento Lingüístico que garanta

8 Idem nota 6. 
que a língua indígena seja a língua de instrução ao longo de todo o processo de escolarização, como sugere Maher (2006), mesmo o bilingüismo das minorias não sendo visto na política nacional como um entrave.

Em novembro de 2004, duas medidas foram tomadas pelo MEC com vistas a elaborar políticas específicas para a educação indígena. No dia primeiro daquele mês, a Portaria $\mathrm{n}^{\circ} 52$ criou uma comissão especial para formular programas voltados para a formação de professores indígenas em nível superior e, duas semanas depois, uma reunião no MEC formava outra comissão: a de Apoio e Incentivo à Produção e Edição de Material Didático Específico Indígena. Um dos objetivos desta última é valorizar, ampliar e revitalizar, através de material didático, o uso das línguas indígenas entre as comunidades de índios. Essa comissão é formada por representantes da Organização Geral dos Professores Tikuna Bilíngües, da Comissão Pró-índio do Acre, do Instituto de Pesquisa e Formação em Educação Indígena, da Universidade Federal de Minas Gerais (UFMG) e da Fundação Nacional do Índio (Funai). Mais uma vez aparece, aqui, a presença de outros atores que se somam ao poder público na formulação da política lingüística e de educação indígena, com destaque para as próprias organizações indígenas.

A UFMG levou para essa comissão formada no MEC a sua experiência no assunto, que também tem forte participação dos próprios índios: através de sua editora, a universidade publicou em 2000 o livro Shenipabu Miyui: história dos antigos, uma coletânea de lendas indígenas contadas, escritas e ilustradas por índios Kaxinawá e realizada pela Organização dos Professores Indígenas do Acre e pela Comissão Pró-Índios do Acre. São histórias como a da Feiticeira Cega, do Relâmpago e do Trovão, da Arara Misteriosa e da Origem dos Remédios da Mata, que aparecem no livro em versões bilíngües: kaxinawá e português. A idéia da comissão formada pelo MEC é que a literatura indígena de lendas e mitos de cada etnia passe a ser estudada nas escolas de suas respectivas comunidades.

A continuidade dessa política é anunciada em março de 2005, durante o $1^{\circ}$ Seminário Nacional de Material Didático Indígena, que contou com a participação de professores indígenas e representantes das secretarias estaduais de educação e de organizações não-governamentais. No evento, Kleber Gesteira Matos anunciou o compromisso do MEC de investir R \$ 800 mil, naquele ano, na produção de material didático específico para os índios, incluindo CDs e vídeos com a participação das próprias comunidades indígenas, com o objetivo de valorizar a tradição oral através da reprodução de cânticos, discursos e narrativas. Em depoimento à revista $\mathrm{ComCiência}{ }^{9}$, ele destaca que tudo isso é 
fruto da reivindicação dos próprios índios e que o peso deles nas políticas de educação indígena é total.

No Seminário, foram apresentadas experiências positivas, como as rádios comunitárias existentes em algumas aldeias, e negativas, como a dificuldade de se trabalhar com materiais didáticos que não valorizam as experiências culturais de cada etnia. Na ocasião, o MEC se comprometeu a apoiar a produção de novos materiais didáticos que valorizariam a cultura oral indígena e que os próprios índios ajudariam a elaborar. Os pontos de partida das discussões no Seminário foram os artigos 78 e 79 da Lei de Diretrizes e Bases da Educação Nacional. Como já apontamos acima, eles asseguram que a educação indígena ofereça, além dos principais aspectos da cultura ocidental, ou seja, da cultura do não-índio, um ensino que valorize os conhecimentos tradicionais dos povos indígenas, suas práticas culturais e suas línguas. Professores e líderes indígenas como o Xavante Lucas Roriô, de Mato Grosso, e o Macuxi Fausto da Silva, de Rondônia, se queixaram no evento da forma como o índio e sua cultura aparecem nos materiais didáticos tradicionais e nos programas educacionais em geral.

De acordo com Kleber Gesteira Matos, do MEC, além de existir uma indústria do material didático já consolidada, a qual não valoriza a cultura indígena, o próprio MEC tem feito pouco nessa área. Segundo ele, a diferença marcada pelo Seminário foi a decisão de produzir material didático de autoria dos próprios índios. O coordenador-geral de Educação Escolar Indígena defende que, embora a escola seja o espaço da comunicação, aprendizado e difusão da escrita, "a oralidade é importante para qualquer cultura" 10 . E para os povos indígenas, de cultura tradicionalmente oral, essa importância é ainda maior, como reforça o professor indígena Xavante, Lucas Roriô: "Nossos antepassados passavam a cultura por meio do diálogo. Há uma tradição dos povos indígenas em absorver o conhecimento oralmente" 11 .

A maior dificuldade, em termos de infra-estrutura para utilização desse material audiovisual produzido com o apoio do MEC, é o uso de TV e vídeo. Menos de um quinto das mais de 2 mil escolas indígenas do país têm esse recurso. No caso de aparelhos de som que tocam CD ou cassete, muitos dos próprios professores indígenas possuem um: os índios que são professores se diferenciam, em termos de status, dos demais de sua etnia, pois são funcionários do Estado, recebem salário, podem comprar eletrodomésticos. E quando não há o aparelho na escola, é possível que haja na casa comunitária, na casa do cacique ou no posto da Funai.

10 Ver "MEC reforça a participação dos índios na produção de materiais didáticos", em seção de notícias da revista ComCiência, março de 2005.

11 Idem nota 7. 
O uso de mídia em comunidades indígenas também aparece no projeto da Secretaria de Educação a Distância do MEC, que inseriu em algumas aldeias do Norte e do Centro-Oeste a Rádio Escola. Trata-se de uma rádio comunitária de baixa potência, com alcance apenas nos arredores da aldeia, na qual os programas produzidos pelos próprios índios e voltados para os índios, além de fortalecer a sua cultura, também são destinados a serviços de interesse da comunidade, como programas de prevenção de saúde, por exemplo.

Para conquistas como essas, Maria Helena Fialho, responsável pela Coordenação Geral de Educação da Funai, reforça que os indígenas têm participado ativamente nos fóruns organizados pelo MEC em parceria com o órgão indigenista federal, nas audiências públicas e em outras reuniões. A Funai, que outrora geria a educação indígena em todo o país, atua atualmente no incentivo à participação dos índios nas discussões nessa área, já que a coordenação das ações escolares de educação indígena está, atualmente, a cargo do MEC, e a sua execução, a cargo dos Estados e Municípios.

Fialho afirma que "a Funai, através de Oficinas de Políticas Públicas, tem buscado levar elementos para que os povos indígenas possam exercer o controle social sobre os diversos programas do MEC, como o FNDE e o Fundef, entre outros, objetivando atingir o maior número de comunidades para esse controle" 12 . A Comissão Nacional de Professores ampliou o número de representantes indígenas, e os professores indígenas participam ainda dos conselhos municipais e estaduais e têm, inclusive, uma representante no Conselho Nacional de Educação.

Além de promover oficinas, a Funai também publicou e distribuiu, entre 2003 e 2004, cartilhas para os Tupari, os Kalapalo, os Potiguara, os CintaLarga, os Karajá e os Bakairi. Essa atividade da Funai de edição e distribuição de material didático específico para os indígenas, no entanto, foi extinta e já não faz parte do Plano Plurianual do governo federal. Já o MEC investiu, no decorrer de 2005, um total de $\mathrm{R} \$ 1$ milhão em material didático para os índios e $\mathrm{R}$ \$ 2 milhões na formação de 3 mil professores indígenas que ainda não haviam concluído o ensino médio. Essa formação é feita em regime de alternância, com um período de ensino intensivo de quatro semanas em um centro de formação e outro período de estudos realizados na própria aldeia, que podem eventualmente contar com a visita de tutores.

Outra prioridade do MEC e das organizações indígenas e das voltadas para as comunidades de índios - sem as quais a política de línguas e de educação indígena no Brasil talvez fosse outra - é o aumento do número de licenciaturas específicas para professores indígenas. A Universidade Estadual do Mato Grosso

12 Idem nota 5. 
foi pioneira ao oferecer, em 2001, o primeiro curso específico de licenciatura do país para cerca de 200 indígenas de 35 etnias. Segundo o Censo da Educação Indígena de 2002 , menos de $2 \%$ dos professores indígenas tinham o $3^{\circ}$ grau e $44 \%$ sequer possuíam o ensino médio. Esse mesmo levantamento apontava que apenas $54 \%$ das escolas indígenas utilizavam aspectos da cultura do índio em seu currículo. As licenciaturas específicas, além de aumentar a escolaridade indígena, têm como objetivo o retorno do índio para sua própria comunidade, onde deverá atuar ou continuar atuando como professor e utilizará aspectos da cultura de sua etnia em sala de aula.

Além da Universidade Estadual de Mato Grosso, que em 2005 contava com 294 indígenas matriculados em licenciatura, em 2003, a Universidade Federal de Roraima criou, com a mesma finalidade, a Licenciatura Intercultural, que tinha 120 alunos em 2005. De acordo a Secretaria de Educação Superior (Sesu) do MEC, além desses 414 indígenas cursando licenciaturas, há cerca de 850 cursando habilitações diversas em instituições particulares de ensino superior e aproximadamente 300 estudando em outras instituições públicas do país. Segundo o coordenador-geral de Educação Escolar Indígena, a intenção do MEC é induzir e apoiar, através da Sesu e da Secad, parcerias com universidades para a criação de novos cursos para professores indígenas.

Dos índios que se aventuram fora das aldeias para aumentar sua escolaridade, não são apenas os estudantes de licenciaturas que retornam à sua terra para atuarem como professores indígenas. João Nonoy, que se tornou em 2003 o primeiro índio do Maranhão com graduação em Direito (que ele cursou em Tocantins), retornou à aldeia Krikati prometendo lutar por causas ambientais e indígenas. E o Terena Rogério Ferreira, que é agrônomo e está cursando um doutorado na Universidade Federal de Londrina, voltou para o seu estado de origem, o Mato Grosso do Sul, após completar os créditos obrigatórios de disciplinas, com a intenção de desenvolver um projeto de sustentabilidade em agricultura, educação e saúde para os povos indígenas. O índio Krikati, do Maranhão, diz que atuar na defesa do seu povo sempre foi a prioridade em sua vida, e avalia que na cidade, as pessoas se preocupam muito de forma individual, e já na aldeia, "há uma união do grupo muito grande. Sabemos que não somos só um. Devemos unir e buscar forças um no outro"13.

13 Ver "Políticas públicas privilegiam a diversidade étnica", em seção de notícias da revista ComCiência, novembro de 2004. 


\section{Considerações finais}

Exemplos como os apontados acima mostram que mesmo a língua indígena não sendo a língua de instrução ao longo de todo o processo de escolarização - já que os cursos superiores no Brasil são em português -, a vontade dos índios e sua consciência política pautada no interesse coletivo pode reverter o conhecimento adquirido através do ensino em benefício para sua comunidade de origem. Mostram, ainda, que eles próprios são os principais atores políticos das ações envolvendo o seu povo, seja em relação à língua, ao ensino ou a qualquer outro direito coletivo. A legislação brasileira atual, em termos de política lingüística e de educação indígena, é, sem dúvida, avançada em comparação com as constituições da década de 1930 em toda a América espanhola, que "explicitam seu repúdio às línguas indígenas e traçam as bases do projeto de extirpação e a obrigatoriedade do espanhol como língua de instrução" (ALFARO, 2001, p. 40). Mas na infindável luta pela garantia de direitos, as lideranças indígenas são e continuarão sendo as principais responsáveis pelas conquistas dos índios. Este artigo, ao focar o tema das políticas lingüísticas no país, procurou apontar como essas lideranças foram importantes no avanço da própria legislação, nos projetos de planejamento lingüístico, no fortalecimento do ensino bilíngüe e na valorização de uma educação indígena que atendesse aos interesses de suas respectivas comunidades.

\section{REFERÊNCIAS}

A ORIGEM e o destino das línguas. ComCiência, n. 23, ago. 2001. Disponível em: <http://www.comciencia.br/reportagens/linguagem/ling08.htm>. Acesso em: 19/3/2008.

ALFARO, Consuelo. As políticas lingüísticas e as línguas ameríndias. Liames, n. 1, p. 31-41, 2001.

AS LÍNGUAS indígenas da Amazônia. ComCiência, n. 15, nov. 2000. Disponível em: $<$ http://www.comciencia.br/reportagens/amazonia/amaz5.htm>. Acesso em: 19/3/2008.

COOPER, Robert. Language planning and social change. Cambridge (Inglaterra): Cambridge University Press, 1989. 
CRYSTAL, David. The Cambridge encyclopedia of language. Cambridge: Cambridge University Press, 1997.

CUCHE, Denys. A noção de cultura nas ciências sociais. Tradução: Viviane Ribeiro. Bauru: EDUSC, 2002.

FARACO, Carlos Alberto. Questões de política de língua no Brasil: problemas e implicações. Educar em Revista, n. 20, p. 13-22, 2002.

FRANCHETTO, Bruna. O conhecimento científico das línguas indígenas da Amazônia no Brasil. In: QUEIXALÓS, F.; RENAULT-LESCURE, O. (Org.). As línguas amazônicas hoje. 1. ed, v. 1. São Paulo: Instituto Socioambiental, 2000. p. 165-182.

LUCY Seki e o indigenismo. ComCiência, n. 15, nov. 2000. Disponível em: $<$ http:// www.comciencia.br/reportagens/amazonia/amaz7.htm>. Acesso em: 19/3/2008.

MAHER, Terezinha Machado. Do casulo ao movimento: a suspensão das certezas na educação bilíngüe e intercultural, 2006. (no prelo)

MAHER, Terezinha Machado. Ser professor sendo índio: questões de língua(gem) e identidade. Tese (Doutorado) - Campinas: IEL/Unicamp, 1996.

MEC reforça a participação dos índios na produção de materiais didáticos. ComCiência, mar. 2005, seção de notícias. Disponível em: <http://www.comciencia.br/ noticias/2005/03/ educacao_indigena.htm>. Acesso em: 19/3/2008.

MELIÁ, Bartolomeu. Palabra vista, dicho que no se oye. In: LÓPEZ, L. E.; JUNG, I. (Orgs.). Sobre las huellas de la voz - sociolingüística de la oralidad y la escritura em su relación com la educación. Madri: Ediciones Morata, 1998.

MUSEU expõe multiplicidade e a história da língua portuguesa. Ciência \& Cultura, n. 3, ano 58, p. 6-7, jul. 2006.

POLÍTICAS públicas privilegiam a diversidade étnica. ComCiência, nov. 2004, seção de notícias. Disponível em: <http://www.comciencia.br/200411/noticias/4/indigena. htm>. Acesso em: 19/3/2008.

RODRIGUES, Aryon. Línguas indígenas: 500 anos de descobertas e perdas. DELTA, v. 9, n. 1, p. 83-103, 1993.

SILVA, Marcio Ferreira da. A conquista da escola: educação escolar e movimento de professores indígenas no Brasil. Em Aberto, Brasília, ano 14, n. 63, p. 38-53, 1994. 
SILVA, Rosa Helena Dias da. A autonomia como valor e articulação de possibilidades: O movimento dos professores indígenas do Amazonas, de Roraima e do Acre e a construção de uma política de educação escolar indígena. Cadernos Cedes, ano XIX, n. 49 , p. $62-75,1999$.

TOLLEFSON, James W. Planning language, planning inequality. Londres: Longman, 1991.

Texto recebido em 27 de novembro de 2006.

Texto aprovado em 16 de janeiro de 2008. 